\title{
Pengaruh aktivitas fisik terhadap kapasitas memori kerja pada pelajar SMA
}

\author{
Rizvialdi $^{1}$ Nuryani Sidarta ${ }^{2}$
}

\begin{abstract}
ABSTRAK
\section{LATAR BELAKANG}

Memori kerja merupakan salah satu bagian dari fungsi eksekutif otak yang dinilai sangat penting untuk menunjang kemampuan proses belajar siswa sekolah. Penelitian menunjukan bahwa prevalensi anak dengan kapasitas memori kerja yang rendah adalah sekitar $15 \%$, dan $80 \%$ anak tersebut mengalami kesulitan akademik. Hasil penelitian menunjukan hubungan kuat antara aktivitas fisik dengan fungsi kognitif otak, terutama memori kerja. Penelitian lain memperlihatkan korelasi lemah antara aktivitas fisik dengan fungsi kognitif otak. Oleh karena itu, peneliti ingin melihat kembali hubungan antara aktivitas fisik dengan kemampuan memori kerja khususnya siswa SMA di Jakarta.

\section{METODE}

Penelitian ini menggunakan studi analitik observasional dengan desain cross-sectional (potong-silang). Teknik pengambilan sampel pada penelitian ini menggunakan teknik non random consecutive sampling yang melibatkan siswa SMAN 54 Jakarta. Jumlah responden yang didapat adalah sebanyak 56 siswa. Pengambilan data menggunakan instrumen kuesioner IPAQ untuk intensitas dan frekuensi aktivitas fisik serta WISC-IV mengukur indeks memori kerja. Analisis data dilakukan dengan uji korelasi Gamma.
\end{abstract}

\section{HASIL}

Terdapat korelasi antara intensitas aktvitas fisik dengan indeks memori kerja $(\mathrm{r}=0.487 ; \mathrm{p}=0.023)$. Selain itu juga terdapat hubungan antara frekuensi aktivitas fisik dengan indeks memori kerja $(r=0.220 ; \mathrm{p}=0.458)$.

\section{KESIMPULAN}

Terdapat korelasi positif antara intensitas aktivitas fisik dan kemampuan memori kerja pada pelajar SMA. Hal ini berarti bahwa semakin tinggi intensitas aktifitas fisik yang dilakukan oleh seorang siswa maka semakin tinggi pula kemampuan memori siswa tersebut.

Kata kunci : aktivitas fisik, memori kerja, pelajar SMA

\author{
${ }^{1}$ Program Studi Kedokteran, \\ Fakultas Kedokteran, \\ Universitas Trisakti \\ 2 Departemen Anatomi, \\ Fakultas Kedokteran, \\ Universitas Trisakti
}

\section{Korespondensi:}

Nuryani Sidarta

Departemen Anatomi,

Fakultas Kedokteran,

Universitas Trisakti,

Jalan Kyai Tapa No. 260, Grogol,

Jakarta Barat

Email:

nuryani_sidarta@trisakti.ac.id

J Biomedika Kesehat 2019;2(2):58-64 DOI: 10.18051/JBiomedKes.2019.

v2.58-64

pISSN: 2621-539X / eISSN: 2621-5470

Artikel akses terbuka (open access) ini didistribusikan di bawah lisensi Creative Commons Attribution 4.0 International (CC-BY 4.0) 


\section{ABSTRACT}

\section{The role of physical activity to working memory capacity in senior high school students}

\section{BACKGROUND}

Working memory is the executive functions of the brain that have a very important role in supporting the learning ability of school students. Reseachs show that poor working memory affects approximately $15 \%$ of children, and $80 \%$ of these children experience difficultis academic. The study results showed a strong relationship between physical activity and cognitive functions of the brain, especially working memory. Other studies have shown a weak correlation between physical activity and brain cognitive function. Therefore, researchers want to see the relationship between physical activity and working memory abilities, especially high school students in Jakarta.

\section{METHODS}

This research used an observational analytic study with cross-sectional design. Non Random consecutive sampling technique used in which of students at SMAN 54 Jakarta. The number of respondents was 56 students. Data retrieval uses the IPAQ questionnaire instrument for the intensity and frequency of physical activity. In addition, we use WISC-IV to measure the index of working memory. Data analysis used gamma correlation test.

\section{RESULT}

The results of these study showed positive correlation between physical activity and working memory index $(\mathrm{r}=0.487 ; \mathrm{p}=0.023)$. A weak positive correlation between the frequency of physical activity and the working memory index $(\mathrm{r}=0.220 ; \mathrm{p}=0.458)$.

\section{CONCLUSION}

It can be concluded that there is a moderate positive correlation between physical activity intensity and working memory capacity in high school students.

Keywords : physical activity, working memory, high school students

\section{PENDAHULUAN}

Memori kerja (working memory) merupakan salah satu fungsi eksekutif pada otak manusiayang bertanggungjawabuntukmenyimpan dan memanipulasi informasi untuk waktu yang singkat. ${ }^{(1,2)}$ Oleh karena itu, memori kerja tentunya sangat penting untuk menunjang kemampuan anak dalam memperoleh pengetahuan dan keterampilan baru. ${ }^{(2)}$ Hasil penelitian menunjukan bahwa prevalensi anak dengan kapasitas memori kerja yang rendah adalah sekitar $15 \%$, dan $80 \%$ dari anak tersebut mengalami kesulitan akademik. (3) Hasil penelitian menunjukkan bahwa fungsi aktivitas fisik dan kebugaran kardiorespirasi tidak hanya untuk pencegahan penyakit kronis saja, tetapi juga berhubungan dengan kognitif dan kesehatan otak. Penelitian yang dilakukan Castelli, et al (2007) menunjukan bahwa kapasitas kardiorespirasi yang besar berhubungan dengan prestasi akademik yang lebih baik pada remaja. Penelitian eksprerimental yang dilakukan oleh Kamijo, et al (2011) menyimpulkan bahwa pemberian aktivitas fisik selama 9 bulan dapat meningkatkan kapasitas memori kerja pada anak remaja. ${ }^{(4)}$ Hasil yang sama juga didapatkan pada penelitian yang dilakukan oleh Ji Qingchun, et al (2017) di Cina. Penelitian tersebut menyimpulkan peningkatan aktivitas fisik berhubungan dengan peningkatkan memori kerja visuospasial pada kalangan mahasiswa. ${ }^{(5)}$ Hasil penelitian di Indonesia menunjukan bahwa terdapat korelasi positif namun lemah antara aktivitas fisik dengan memori kerja pada pelajar SMA. ${ }^{(6)}$

Penelitian-penelitian tersebut di atas telah menunjukan adanya hubungan antara aktivitas fisik dengan fungsi kognitif dan memori kerja, nyatanya di Indonesia data Riskesdas tahun 2013 menunjukan bahwa DKI Jakarta memiliki angka proporsi tertinggi dari aktivitas fisik tergolong kurang aktif dengan persentase $44.2 \%$ pada remaja. ${ }^{(7)}$ Hal ini meningkatkan kewaspadaan terhadap kurangnya aktivitas fisik dengan kemampuan memori kerja pelajar di Jakarta yang akan mempengaruhi proses belajar mereka.

Berdasarkan uraian di atas hasil penelitian tentang hubungan antara aktivitas fisik dengan kemampuan memori kerja masih kontradiktif, maka peneliti ingin mengetahui hubungan antara aktivitas fisik dengan kemampuan memori kerja pada siswa SMA di Jakarta. Harapan dari penelitian ini adalah untuk meningkatkan kesadaran dari masyarakat dan pelajar tentang peran aktivitas fisik terhadap kemampuan belajar di sekolah.

\section{METODE}

Penelitian ini dilakukan menggunakan metode analitik observasional dengan pendekatan cross-sectional. Penelitian ini 
dilaksanakan pada bulan Agustus - September 2018 dengan melibatkan 56 siswa di SMAN 54 Jakarta Timur yang dipilih secara non random consecutive sampling. Siswa yang menderita retardasi mental atau lahir dari ibu yang menderita retardasi mental, mempunyai gangguan neurologis seperti trauma, infeksi sistem saraf pusat (SSP), kejang atau epilepsi, memiliki gangguan psikologis seperti stress, depresi, keinginan bunuh diri, cemas, oposisi, perilaku conduct tidak dimasukkan sebagai subjek penelitian.

Instrumen yang digunakan untuk mengukur intensitas dan frekuensi aktivitas fisik adalah kuesioner IPAQ (International Physical Activity Questionnaire). ${ }^{(8)}$ Untuk memastikan siswa mengerti pertanyaan yang terdapat di kuesioner IPAQ maka peneliti mendampingi siswa selama proses pengisian. Untuk penggolongan intensitas aktivitas fisik dibagi berdasakan pedoman dari IPAQ dimana yang dimaksud dengan intensitas rendah adalah aktivtas fisik yang hanya menghabiskan 600 METs per minggu dan intensitas tinggi adalah aktivitas fisik yang menghabiskan lebih dari 1500 METs per minggu. Aktivitas yang menghabiskan $>600$ METs sampai dengan $<1500$ METs digolongkan menjadi kelompok aktivitas dengan intensitas sedang. Untuk penggolongan frekuensi aktivitas fisik, peneliti membagi menjadi ringan, sedang, dan berat. Subjek penelitian digolongkan dalam kelompok frekuensi aktivitas tinggi apabila melakukan aktivitas fisik $\geq 5$ kali per minggu dan frekuensi rendah apabila aktivitas fisik kurang dari 3 kali per minggu. Kelompok yang memiliki frekuensi di antaranya dimasukkan dalam kelompok dengan aktivitas fisik dengan frekuensi sedang.

Untuk mengukur kemampuan memori kerja, peneliti menggunakan instrumen WISC-IV. Para subjek diberikan pertanyaan sesuai dengan protokal dan nilai yang didapat kemudiann dibandingkan dengan nilai anak lain seusianya. Kemampuan memori kerja kemudian akan dikelompokkan menjadi 3 kategori yaitu di atas rata-rata, rata-rata dan di bawah rata-rata. Uji statistik yang dipilih adalah uji korelasi Gamma karena merupakan uji yang diprioritaskan untuk uji hipotesis korelatif variabel ordinal dengan ordinal.
Penelitian ini sudah mendapatkan persetujuan kaji etik dari FK Trisakti dengan no 20/KER-FK/VIII/2018.

\section{HASIL}

\section{Karakteristik responden}

Tabel 1. Distribusi frekuensi karakteristik responden $(\mathrm{n}=56)$

\begin{tabular}{|c|c|c|}
\hline $\begin{array}{l}\text { Karakteristik } \\
\text { responden }\end{array}$ & $\begin{array}{c}\text { Frekuensi } \\
\text { (n) }\end{array}$ & $\begin{array}{c}\text { Presentase } \\
(\%)\end{array}$ \\
\hline \multicolumn{3}{|l|}{ Usia } \\
\hline 14 & 10 & 17.9 \\
\hline 15 & 29 & 51.8 \\
\hline 16 & 17 & 30.4 \\
\hline \multicolumn{3}{|l|}{ Jenis Kelamin } \\
\hline Laki-laki & 24 & 42.9 \\
\hline Perempuan & 32 & 57.1 \\
\hline \multicolumn{3}{|l|}{ Kelas } \\
\hline $\mathrm{X}$ & 29 & 51.8 \\
\hline XI & 27 & 48.8 \\
\hline \multicolumn{3}{|l|}{ Prestasi Akademik } \\
\hline Diatas rata-rata & 25 & 44.6 \\
\hline Rata-rata & 2 & 3.6 \\
\hline Dibawah rata-rata & 29 & 51.8 \\
\hline \multicolumn{3}{|c|}{ Indeks Memori Kerja } \\
\hline Diatas rata-rata & 17 & 30.4 \\
\hline Rata-rata & 36 & 64.3 \\
\hline Dibawah rata-rata & 3 & 5.4 \\
\hline \multirow{2}{*}{\multicolumn{3}{|c|}{$\begin{array}{l}\text { Aktivitas Fisik } \\
\text { Intensitas Aktivitas } \\
\text { Fisik }\end{array}$}} \\
\hline & & \\
\hline Sangat aktif & 22 & 39.3 \\
\hline Moderat & 18 & 32.1 \\
\hline Kurang aktif & 16 & 28.6 \\
\hline \multirow{2}{*}{\multicolumn{3}{|c|}{$\begin{array}{l}\text { Frekuensi Aktivitas } \\
\text { Fisik }\end{array}$}} \\
\hline Fisik & & \\
\hline Tinggi & 42 & 75.0 \\
\hline Moderat & 13 & 23.2 \\
\hline Rendah & 1 & 1.8 \\
\hline
\end{tabular}

Keterangan: $\mathrm{n}=$ jumlah subjek; $\%=$ persentase

Penelitian ini melibatkan 56 siswa dari kelas X dan XI dengan rentang usia dari 14 sampai 16. Prestasi akademik diambil dari rata-rata rapot semester genap tahun ajaran 2017/2018 dari masing-masing kelas dan dikategorikan menjadi 3 kategori yaitu prestasi akademik diatas rata-rata, rata-rata, dan dibawah rata-rata. Dari tabel di atas terlihat terlihat 29 siswa (51.8\%) yang memiliki prestasi akademik yang dibawah rata-rata.

Dari 56 siswa yang diukur kapasitas memori kerjanya, didapatkan lebih dari separuh siswa $(64.3 \%)$ yang memiliki kapasitas memori di level rata-rata bila dibandingkan dengan anak lain seusianya. Terdapat tiga orang siswa (5.4\%) yang memiliki kapasitas memori di bawah rata- 
Tabel 2. Hubungan intensitas dan frekuensi aktivitas fisik dengan kemampuan memori kerja

\begin{tabular}{|c|c|c|c|c|c|c|}
\hline \multirow{2}{*}{\multicolumn{2}{|c|}{ Variabel }} & \multicolumn{3}{|c|}{ Indeks memori kerja } & \multirow[b]{2}{*}{$\mathbf{r}$} & \multirow[b]{2}{*}{$\mathbf{p}$} \\
\hline & & $\begin{array}{c}\text { Di atas } \\
\text { rata-rata }\end{array}$ & Rata-rata & $\begin{array}{l}\text { Di bawah } \\
\text { rata-rata }\end{array}$ & & \\
\hline \multirow{3}{*}{$\begin{array}{c}\text { Intensitas aktivitas } \\
\text { fisik }\end{array}$} & Sangat aktif & 11 & 10 & 1 & \multirow{3}{*}{$0.487 \#$} & \multirow{3}{*}{$0.023 \#$} \\
\hline & Moderat & 3 & 15 & - & & \\
\hline & Kurang aktif & 3 & 11 & 2 & & \\
\hline \multirow{3}{*}{$\begin{array}{l}\text { Frekuensi aktivitas } \\
\text { fisik }\end{array}$} & Sangat aktif & 14 & 26 & 2 & \multirow{3}{*}{$0.220 \#$} & \multirow{3}{*}{$0.458 \#$} \\
\hline & Moderat & 2 & 10 & 1 & & \\
\hline & Kurang aktif & 1 & - & - & & \\
\hline
\end{tabular}

\#: Uji korelasi Gamma

rata anak seusianya.

Berdasarkan data mengenai intensitas dan frekuensi aktivitas fisik para siswa, terlihat bahwa mayoritas responden (75\%) memiliki frekuensi aktivitas fisik yang tergolong tinggi. Hal ini berarti bahwa mayoritas siswa melakukan aktifitas fisik setidaknya lebih dari 5 kali per minggu. Namun dari segi intensitas, terdapat pembagian yang cukup merata antara kelompok siswa yang memiiliki intensitas tinggi, rata-rata dan rendah. Hasil pada studi ini menunjukkan hanya $39.3 \%$ yang memiliki intensitas tinggi. Hal ini mengindikasikan bahwa walaupun para siswa memiliki frekuensi aktivitas fisik yang tinggi namun tidak diikuti dengan intensitas fisik yang tinggi pula. Tabel 1 menunjukkan $28.6 \%$ siswa memiliki intensitas fisik rendah yang berarti bahwa aktivitas yang dilakukan walaupun sering hanya mencapai kurang dari 600 METs per minggu.

\section{Hubungan antara aktivitas fisik dengan kemampuan memori kerja}

Berdasarkan Tabel 2 dapat diketahui bahwa pada kelompok siswa yang memiliki indeks memori kerja diatas rata-rata, sebagian besar diantaranya $(65 \%)$ memiliki intensitas aktivitas fisik yang tergolong sangat aktif. Setelah dianalisis menggunaka uji korelasi Gamma, didapatkan angka koefesien korelasi $\mathrm{r}=0.487$ yang artinya terdapat korelasi positif sedang antara kedua variabel. Angka koefesien korelasi $r$ bernilai positif sehingga hubungan kedua variabel tersebut bersifat searah dapat diartikan bahwa semakin meningkatnya intensitas aktivitas fisik, maka semakin baik pula indeks memori kerja. Nilai signifikasi yang kurang dari dari 0.05 menunjukan terdapat hubungan bermakna atau signifikan antara intesitas aktivitas fisik dengan indeks memori kerja. Hasil analisis diatas mengindikasikan bahwa terdapat korelasi positif sedang yang bermakna secara staatistik antara aktivitas fisik dan indeks memori kerja.

Tabel 2 memberikan gambaran distribusi hubungan antara frekuensi aktivitas fisik dengan indeks memori kerja. Hasil di atas juga menunjukan bahwa dari 17 siswa yang memiliki kemampuan memori kerja di atas rata-rata maka 14 diantaranya (82\%) memiliki frekuensi aktifitas fisik yang tinggi.

Hasil uji korelasi Gamma antara kedua variabel didapatkan nilai koefesien korelasi $\mathrm{r}=0.220$. Hal ini berarti terdapat korelasi positif lemah antara kedua variabel dengan $p=0.458$ $(\mathrm{p}>0.05)$. Hal ini berarti bahwa tidak terdapat hubungan bermakna atau signifikan antara frekuensi aktivitas fisik dengan kemampuan memori kerja.

\section{Hubungan antara indeks memori kerja dengan prestasi akademik}

Tabel 3. Hubungan indeks memori kerja dengan prestasi akademik

\begin{tabular}{|c|c|c|c|c|c|c|}
\hline \multirow{2}{*}{\multicolumn{2}{|c|}{ Variabel }} & \multicolumn{3}{|c|}{ Prestasi akademik } & \multirow[b]{2}{*}{$\mathbf{r}$} & \multirow[b]{2}{*}{$\mathbf{p}$} \\
\hline & & $\begin{array}{c}\text { Di atas } \\
\text { rata-rata }\end{array}$ & Rata-rata & $\begin{array}{l}\text { Di bawah } \\
\text { rata-rata }\end{array}$ & & \\
\hline \multirow{3}{*}{$\begin{array}{l}\text { Indeks memori } \\
\text { kerja }\end{array}$} & Di atas rata-rata & 13 & - & 4 & \multirow{3}{*}{$0.646 \#$} & \multirow{3}{*}{$0.003 \#$} \\
\hline & Rata-rata & 11 & 2 & 23 & & \\
\hline & Di bawah rata-rata & 1 & - & 2 & & \\
\hline
\end{tabular}

\#: Uji korelasi Gamma 
Berdasarkan analisis Tabel 3 menggunakan uji korelasi Gamma, didapatkan angka koefesien korelasi $\mathrm{r}=0.646$ yang artinya terdapat korelasi yang positif kuat dari kedua variabel. Korelasi positif menunjukan bahwa semakin baik indeks memori kerja maka semakin baik pula prestasi akademiknya. Selain itu, diperoleh juga $\mathrm{p}=0.003$ yang menunjukan nilai kemaknaan $\mathrm{p}<0.05$, sehingga menunjukan terdapat hubungan bermakna atau signifikan antara prestasi akademik dengan kemampuan memori kerja. Hasil di atas mengindikasikan adanya korelasi positif kuat yang bermakna secara statistik antara indeks memori kerja dengan prestasi akademik.

\section{PEMBAHASAN}

Hasil pengukuran intensitas dan frekuesi aktifitas fisik pada penelitian ini menunjukkan bahwa sebagian besar responden memiliki intensitas dan frekuensi aktifitas fisik yang tinggi. Hal ini berbeda dengan data Riskesdas tahun 2013 yang menunjukan bahwa DKI Jakarta adalah peringkat teratas dari 5 provinsi yang memiliki angka proporsi tertinggi dari aktivitas fisik tergolong kurang aktif dengan persentase $44.2 \%$ pada remaja ${ }^{(7)}$. Namun demikian, tingginya frekuensi aktivitas fisik tidak bersamaan dengan tingginya intensitas aktivitas fisik. Sebagian besar responden memiliki frekuensi aktifitas yang tinggi namun tidak diikuti dengan intensitas yang tinggi. Hal ini dapat dijelaskan karena karena intensitas fisik tidak hanya dipengaruhi oleh frekuensi aktivitas tetapi juga dipengaruhi oleh tingkat dan jenis aktivitas fisik (vigorous, moderate, walking) dan juga lama waktu individu melakukan aktivitas fisik tersebut. ${ }^{(8)}$ Berdasarkan uraian di atas, peneliti melihat bahwa perbedaan hasil ini dapat disebabkan oleh perubahan pada kurikulum sekolah tahun 2013 dimana siswa diberikan pelajaran olahraga setidaknya 2 jam 15 menit per minggu. Selain itu, siswa juga diwajibkan mengikuti kegiatan ekstrakulikuler dan mayoritas siswa memilih ekstrakurikuler yang berkaitan dengan aktifitas fisik seperti futsal maupun basket. Selain itu, sebagian besar siswa juga menggunakan trasnportasi umum yang mengharuskan para siswa untuk lebih banyak berjalan. Terlihat bahwa perubahan kurikulum sekolah yang menambah jam pelajaran olahraga serta anjuran untuk pemakaian transportasi umum dapat menjadi salah satu cara untuk meningkatkan tingkat aktifitas fisik para pelajar.

Dari hasil pengukuran indeks memori kerja didapatkan bahwa sebagian besar siswa memiliki indeks memori kerja di atas rata-rata. Hanya terdapat tiga siswa (5.4\%) yang memiliki indeks memori kerja di bawah rata-rata. Selain itu, mayoritas responden yang memiliki indeks memori kerja di atas rata-rata juga memiliki prestasi akademik yang di atas rata-rata. Dari 17 siswa yang memiliki indeks memori di atas rata-rata maka 13 diantaranya memiliki prestasi akademik yang di atas rata-rata juga. Analisis data menggunakan uji korelasi Gamma menunjukan hasil bahwa terdapat korelasi positif kuat dan bermakna antara prestasi akademik dengan indeks memori kerja dengan nilai $\mathrm{r}=0.646$ dan $\mathrm{p}=0.003$ yang dapat diartikan bahwa semakin baik indeks memori kerja, semakin baik pula prestasi akademiknya. Analisis tersebut sesuai dengan penelitian Swanson dan Alloway (2012) yang menyatakan bahwa terdapat hubungan antara prestasi akademik dengan memori kerja. ${ }^{(9)}$

Pada analisis variabel intensitas aktivitas fisik dengan indeks memori kerja menggunakan uji korelasi Gamma didapatkan $\mathrm{r}=0.487$ dengan $\mathrm{p}=0.023 \quad(\mathrm{p}<0.05)$ yang menunjukan terdapat korelasi positif kuat yang bermakna antara kedua variabel. Arah korelasi yang positif menandakan bahwa dengan intensitas aktivitas fisik yang semakin aktif maka semakin baik kemampuan memori kerja. Hal ini sesuai dengan penelitian yang dilakukan oleh Junaidi et al (2016) yang menunjukan hasil terdapat hubungan bermakna terhadap aktivitas fisik terhadap memori kerja tetapi dengan korelasi positif lemah $(\mathrm{r}=0.384)$. (6) Selain itu, hubungan bermakna antara aktivitas fisik dengan memori kerja juga sesuai dengan penelitian Kamijo et al $(2011)^{(4)}$ dan Ji Qingchun et al (2017) ${ }^{(5)}$ yang menunjukan hasil bahwa aktivitas fisik dapat meningkatkan memori kerja pada kalangan preadolescent dan meningkatkan memori kerja visuospasial pada mahasiswa. Analisis di atas juga didukung oleh penelitian Kramer AF \& Erickson KI (2007) dan Kennedy et al (2017) di mana aktivitas fisik dapat meningkatkan kebugaran kardiorespirasi dan menghasilkan BDNF di dalam tubuh yang dapat meningkatkan kemampuan memori kerja melalui mekanisme peningkatan cerebral blood 
flow dan neurogenesis pada otak. ${ }^{(10,11)}$ Selain itu, aktivitas fisik juga dapat meningkatkan hormon IGF-1 yang akan menghasilkan VEGF untuk angiogenesis pembuluh darah otak, insulin sebagai neuromodulator, dan juga kortisol serta neurotransmitter dopamine, serotonin, dan adrenalin untuk menjaga struktur dan fungsi otak. $(10,11,12,13)$ Struktur dan fungsi otak yang baik dapat meningkatkan kemampuan memori kerja sehingga dapat mempengaruhi proses belajar siswa. ${ }^{(14,15)}$

Hasil lain yang dianalisa dalam penelitian ini adalah melihat hubungan frekuensi aktivitas fisik dengan kemampuan memori kerja. Dari hasil analisis dengan menggunakan uji korelasi Gamma didapatkan $\mathrm{r}=0.220$ dengan $\mathrm{p}=0.458 \quad(\mathrm{p}>0.05)$ yang menunjukan terdapat korelasi positif lemah yang tidak bermakna antara frekuensi aktivitas fisik dengan kemampuan memori kerja. Hal ini mungkin disebabkan oleh frekuensi aktivitas fisik yang cenderung tinggi belum tentu aktivitas tersebut mencapai angka METs yang tinggi. Rumus dari intensitas aktivitas fisik adalah jenis/ berat dari aktivitas fisik (vigorous, moderate, walking) dikalikan dengan frekuensi aktivitas fisik lalu dikalikan waktu aktivitas fisik dalam menit, hasil kalkulasi tersebut memiliki satuan METs/ minute/week sehingga memungkinkan walaupun frekuensi cukup tinggi tetapi mungkin saja responden tidak melakukan aktivitas berat/sedang atau melakukan tetapi durasinya kurang dari 30 menit per hari.

Secara keseluruhan, dari hasil penelitian ini didapatkan bahwa terdapat hubungan bermakna antara intensitas aktivitas fisik dan kemampuan memori kerja dengan korelasi positif kuat. ${ }^{(18,19)}$ Meskipun demikian, dalam penelitian ini terdapat faktor-faktor lain seperti pola tidur ${ }^{(9)}$, kelelahan $^{(10)}$, genetik ${ }^{(20)}$, dan emosi $/ \operatorname{mood}^{(21)}$ yang dapat mempengaruhi kemampuan memori kerja yang perlu dilakukan penelitian lebih lanjut terutama pada siswa SMA. Faktor lain seperti gangguan regulasi neurotransmitter otak (infeksi SSP, cemas, depresi 6 bulan terakhir) dan juga struktur dan fungsi cerebrum (retardasi mental, trauma kepala 6 bulan terakhir) dapat disingkirkan tetapi hanya dengan metode wawancara kepada responden berdasarkan kuesioner penelitian sehingga didapatkan kriteria eksklusi pada penelitian ini. Selain faktor-faktor yang tidak diteliti tersebut, instrument IPAQ yang hanya menanyakan kegiatan aktivitas fisik seminggu terakhir, mungkin saja dalam seminggu terakhir respoden sedang tidak aktif melakukan aktivitas fisik atau bahkan lebih aktif melakukan aktivitas fisik dari sebelumnya, dan karena sistem IPAQ adalah recall ada kemungkinan responden tidak mengingat secara pasti durasi saat melakukan aktivitas fisik. Sedangkan penelitian kohort Kamijo et.al (2011) melakukan intervensi aktivitas fisik selama 150 hari akan lebih efektif dan akurat. (4)

\section{KESIMPULAN}

Dari hasil penelitian yang dilakukan pada pelajar SMA DKI Jakarta, didapatkan bahwa mayoritas siswa memiliki kemampuan memori kerja yang tergolong di atas rata-rata dengan intensitas dan frekuensi aktfitas fisik yang tinggi. Hasil uji korelasi antara indeks memori kerja dengan intensitas aktifitas fisik menunjukkan adanya korelasi positif yang signifikan antar kedua variabel. Hal ini mengindikasikan bahwa semakin tinggi intensitas aktifitas fisik seorang siswa maka semakin tinggi pula indeks memori kerjanya. Pada hubungan antara indeks memori kerja dengan frekuensi aktifitas fisik didapatkan adanya korelasi positif namun hubungan ini dinilai tidak signifikan.

Untuk penelitian selanjutnya, peneliti berharap dapat melakukan penelitian ini di daerah luar Jakarta sehingga dapat lebih memberikan gambaran untuk anak anak Indonesia. Selain itu, perlu juga dilakukan penelitian pada kelompok usia yang lebih dini sehingga apabila terdapat hubungan signifikan maka intervensi dapat dilakukan dengan lebih dini guna meningkatkan prestasi belajar pada siswa. Selain itu juga disarankan untuk penilaian terhadap aktifitas fisik dapat digunakan pengukuran secara langsung seperti penggunaan pedometer, accelorometer maupun arm-bands.

Berdasarkan hasil di atas maka peneliti berharap masyarakat luas lebih memahami tentang pentingnya aktivitas fisik untuk kesehatan tubuh dan memori kerja dalam menunjang prestasi belajar anak anak Indonesia. Para pelajar diharapkan juga dapat melakukan aktifitas fisik yang cukup dan teratur sebagai salah satu strategi untuk meningkatkan prestasi belajar. 


\section{DAFTAR REFERENSI}

1. Diamond A. Executive Functions. Annu Rev Psychol. 2013; 64: 135-68.

2. Wiguna T, WR Setyawati N, Kaligis F. Uji Diagnostik Working Memory Rating Scale (WMRS) versi Bahasa Indonesia dan Proporsi Anak Sekolah Dasar dengan Kesulitan Belajar dan defisit Working Memory di Jakarta. Sari Pediatri. 2012 Oktober; 14(3): 191-7.

3. Holmes J, Gathercole S, Dunning D. Advances in Child Development and Behavior, Developmental Disorder and Intervention, Volume39. 2010

4. Kamijo K, Pontifex MB, O’Leary KC, Scudder MR, Wu Chien-Ting, Castelli DM, Hillman CH. The Effects of an After School Physical Activity Program on Working Memory in Preadolescent Children. Dev Sci. 2011 September ; 14(5): 10461058. Doi:10.1111/j.1467-7687.2011.01054.x.

5. Ji Qingchun, Wang Yingying, Guo Wei, Zhou Chenglin. Contribution of underlying processes to improved visuospatial working memory associated with physical activity. PeerJ. 2017; 5:e3430; Doi:10.7717/peerj.3430

6. Junaidi MC, Soegiarto B. Hubungan antara Aktivitas Fisik Terhadap Memori Kerja Murid SMA Don Bosco III Bekasi. Sari Pediatri 2016;18(4):251-9.

7. Riset Kesehatan Dasar (Rikesdas). Jakarta: Badan Penelitian dan Pengembangan Kesehatan Kementrian Kesehatan RI. 2013.

8. International Physical Activity Questionnaire (IPAQ). Guidelines for Data Processing and Analysis of the International Physical Activity Questionnaire (IPAQ)-Short and Long Forms. 2005 November. Available From: https://sites. google.com/site/theipaq/home. Accessed July 10, 2018.

9. Musich S, Wang SS, Hawkins K, Greame C. The Frequency and Health Benefits of Physical Activity for Older Adults. Marry Ann Liebert, inc. Popul Health Manage. 2016;20(3): 1-8. Doi: 10.1089/ pop.2016.0071

10. Kramer AF \& Erickson KI. Capitalizing on cortical plasticity: influence of physical activity on cognition and brain function. TRENDS in Cognitive Sciences. 2007; 11(8): 344-348.

11. Kennedy G, Hardman RJ, Macpherson H, Scholey AB, Pipingas A. How Does Exercise Reduce the Rate of Age-Associated Cognitive Decline? A Review of Potential Mechanisms. Journal of Alzheimer's Disease. 2017; 55: 1-18.

12. Macpherson H, Teo WP, Schneider LA, Smith AE. A Life-Long Approach to Physical Activity for Brain Health. Front. Aging Neurosci. 2017; 9:147.

13. U.S. Department of Health and Human Services. Physical Activity and Health: A Report of the Surgeon General. Atlanta, GA: U.S. Department of Health and Human Services, Centers for Disease Control and Prevention, National Center for Chronic Disease Prevention and Health Promotion, 1996. pp. 61-77

14. Chai WJ, Hamid Aini IA, Abdullah JM. Working Memory From the Psychological and Neuroscience Perspective: A Review. Front in Psycho. 2018 March; 9(401).

15. Dehn MJ. Working Memory and Academic Learning: Assessment and Intervention. New Jersey: John Wiley \& Sons.2008. pp. 63-90

16. Karlsgodt KH, Bachman P, Winkler AM, Bearden
CE, Glahn DC. Genetic influence on the working memory circuitry: Behavior, structure, function and extensions to illness. Elsevier Behavioural Brain Research 225 (2011) 610-622.

17. Jin Yi-Xiang, Li Xue-Bing, Luo Yue-Jia. Effects of Emotional Content on Working Memory: Behavioral and Electrophysiological Evidence. Springer-Verlag Berlin Heidelberg . 2013. pp. 13644

18. Musich S, Wang SS, Hawkins K, Greame C. The Frequency and Health Benefits of Physical Activity for Older Adults. Marry Ann Liebert Inc. Popul Health Manage. 2016;20(3):1-8. Doi:10.1089/ pop.2016.0071.

19. General Physical Activities Defined by Level of Intensity. Available at: https://www.cdc. gov/nccdphp/dnpa/physical/pdf/pa intensity table 2 1.pdf. Accessed January 28, $2 \overline{0} 19$.

20. Norton K, Norton L, Sadgrove D. Position statement on physical activity and exercise intensity terminology. Journal of Science and Medicine in Sport. 2010; 13: 496-502

21. Miles L. Physical Activity and Health. British Nutrition Foundation, High Holborn House, London, UK.2007. 